\title{
Keanekaragaman Capung (Ordo: Odonata) di Kawasan Hutan Lindung Duriangkang
} Tanjung Piayu Batam

\section{The Diversity Of Dragonflies (Ordo: Odonata) in Duriangkang Protected Forest Area Tanjung Piayu Batam}

\author{
Santiria Simatupang ${ }^{1}$, Fauziah Syamsi $^{2^{*}}$, Rahmi $^{3}$, Yarsi Efendi ${ }^{4}$ \\ ${ }^{1234}$ Program Studi Pendidikan Biologi, Fakultas Keguruan dan Ilmu Pendidikan, \\ Universitas Riau Kepulauan, Indonesia \\ *Koresponden: fauziahsyamsi@gmail.com
}

\begin{abstract}
Abstrak
Hutan Lindung Duriangkang merupakan hutan lindung terluas di kota Batam, yang memiliki peranan penting sebagai daerah resapan air dan menjaga persediaan air bersih dalam menunjang kebutuhan masyarakat sekitar. Keberadaan capung dapat dijadikan sebagai indikator lingkungan karena dalam proses perkembangannya capung membutuhkan lingkungan yang baik untuk menunjang setiap fase kehidupannya. Tujuan penelitian ini adalah untuk mengetahui struktur komunitas capung di kawasan hutan lindung Duriangkang, Tanjung Piayu Batam. Pengambilan data dengan menggunakan metode jelajah (visual day flying) di sepanjang jalur pengamatan. Berdasarkan hasil penelitian ditemukan 24 jenis capung yang terdiri dari 4 Famili dengan total 429 individu. Indeks Keanekaragaman total sebesar 2,709 yang tergolong sedang. Indeks Kemerataan (E) sebesar 0.852 yang tergolong tinggi. Indeks Kekayaan Jenis sebesar 3.794 yang tergolong sedang, Indeks Dominansi total sebesar 0.090 yang tergolong kategori rendah atau tidak terdapat jenis yang mendominansi. Indeks Kesamaan Jenis yang diperoleh dari perbandingan stasiun 1-2 dan 1-3 tergolong sama (62\% dan 63\%) dan indeks kesamaan jenis dari stasiun 2-3 tergolong berlainan (36\%) sehingga kualitas ekosistem pada kawasan Hutan Lindung Duriangkang tergolong stabil dan merata. Kehadiran capung sangat erat kaitannya dengan keberadaan badan perairan di suatu habitat, lebih menyenangi habitat terbuka dengan vegetasi semak dibandingkan hutan dengan hutan dengan tutupan tajuk yang rapat
\end{abstract}

Kata Kunci: Keanekaragaman Capung, Odonata, Hutan Lindung, Duriangkang, Batam

\begin{abstract}
Duriangkang Protected Forest is the largest in Batam city, which has an important role as a water catchment area and keeps clean water supplies in supporting the needs of the surrounding community. The existence of dragonflies can be used as an environmental indicator because in the development process dragonflies need a good environment to support each phase of their lives.The aim of this research is to find out the community structure of the dragonfly in the Duriangkang protected forest area. Sampling of dragonfly was carried out using the visual day flying method along the observation track. Based on the results of the study, it was found 24 species consist of 4 family and 429 undividual. Total Diversity Index of 2.709 was classified as moderate. Evenness Index (E) Type of 0.852 which is classified as high. The Species Wealth Index is 3,794 which is classified as moderate, the total Dominance Index is 0.090 which is categorized as low or there is no type of dominating. Similarity Index Types obtained from the comparison of 1-2 and 1-3 stations are classified as the same (62\% and 63\%) and similarity index types from station 2-3 are classified differently (36\%) so that the quality of ecosystems in the Duriangkang Protected Forest area is classified as stable and equally. The presence of dragonflies is related to the presence of a waterbody in a habitat, preferring open habitats with bush vegetation compared to forests with close canopy cover.
\end{abstract}

Keywords: Diversity of Dragonflies, Odonates, Protected Forest, Duriangkang, Batam 


\section{PENDAHULUAN}

Capung merupakan serangga yang menarik secara visual karena memiliki 4 sayap yang berselaput dan banyak urat sayapnya (Susanti, 1998), memiliki ukuran tubuh relatif besar, berwarna bagus dan menggunakan sebagian besar hidupnya untuk terbang (Amir dan Kahono, 2003; Setiyono et.al., 2017). Secara taksonomi, capung terbagi menjadi 2 sub ordo yaitu Anisoptera (capung biasa) dan Zyoptera (capung jarum) (Hadi et. al., 2009). Capung merupakan serangga dengan penyebaran luas, mulai dari hutan-hutan, kebun, sawah, sungai danau, dan lain-lain. Capung ditemukan mulai dari tepi pantai hingga ketinggian lebih dari $3.000 \mathrm{~m}$ dpl. Beberapa jenis capung, memiliki kemampuan terbang yang baik dan memiliki daya jelajah wilayah yang luas, dan beberapa jenis lainnya merupakan penerbang yang lemah dan daya jelajahnya sempit (Rizal, 2015).

Capung memiliki peran yang sangat penting dalam keseimbangan ekosistem (Pamungkas, 2015). Capung berperan sebagai serangga predator baik dalam bentuk nimfa maupun dewasa, yang memangsa berbagai jenis serangga serta organisme lain termasuk serangga hama (Borror, et. al., 1992). Pemangsaan nimfa capung terhadap jentik-jentik nyamuk di suatu habitat perairan dapat mengendalikan populasi nyamuk. Sebaliknya nimfa capung juga merupakan sumber makanan biota air lainnya seperti kumbang atau kepik air, katak dan ikan (Cafferty,1981). Selain itu capung juga dapat dijadikan sebagai indikator kualitas perairan karena capung hidup di perairan pada saat fase nimfa. Perubahan kualitas perairan sangat berpengaruh pada jumlah nimfa capung sehingga dapat dijadikan sebagai indikator baik dan buruknya perairan tersebut (Rini, 2011 dalam Wijayanto, 2016). Pada kondisi perairan sudah tercemar, siklus hidup capung terganggu dan mengakibatkan jumlah populasi menurun.

Kelestarian capung perlu dipelihara dengan menjaga keberadaan tempat hidupnya yang sebagian besar berupa perairan. Kawasan Hutan Lindung Duriangkang memiliki luas 6,075.00 Ha (Dinas Kelautan, Perikanan, Pertanian, dan Kehutanan Kota Batam, 2014), terdiri dari hutan dan kawasan lahan basah berupa waduk yang menjadi sumber air bersih utama untuk masyarakat setempat. Pada beberapa tempat di hutan Lindung Duriangkang sudah terjadi perubahan fungsi hutan secara ilegal oleh masyarakat, berupa pembukaan lahan untuk perumahan liar, perkebunan, peternakan, aktivitas nelayan, dan tambak ikan.

Kondisi seperti ini secara tidak langsung memberikan dampak terhadap keanekaragaman flora dan fauna yang terdapat pada kawasan tersebut. Mengingat fungsi vital 
hutan lindung Duriangkang bagi masyarakat Kota Batam, serta fungsi ekologis secara keseluruhan, maka kelestarian hutan lindung Duriangkang perlu dijaga. Salah satu upaya dalam pelestarian lingkungan adalah dengan mendata keanekaragaman hayati yang ada pada kawasan tersebut, terutama jenis yang dapat dijadikan sebagi indikator kualitas lingkungan, salah satunya adalah capung. Tujuan penelitian ini adalah untuk mengetahui struktur komunitas capung yang terdiri dari indeks keanekaragaman, indek kekayaan, indeks kemerataan, indeks dominansi dan indeks kesamaan di Kawasan Hutan Lindung Duriangkang, Tanjung Piayu, Kota Batam.

\section{METODOLOGI PENELITIAN}

Penelitian dilaksanakan pada bulan April-Mei 2018 di Kawasan Hutan Lindung Duriangkang. Secara geografis Kawasan Hutan Lindung Duriangkang ini berada $1^{\circ} 02^{\prime} 40.46$ ” Lintang Utara dan 10406'22.13" Bujur Timur. Kawasan Hutan Lindung Duriangkang memiliki topografi mulai dari daratan rendah hingga berbukit. Pengambilan sampel dengan metode jelajah (visual day flying) pada waktu aktif capung yaitu pagi hari (pukul 07.00 10.00 WIB) dan sore hari (pukul 15.00 sampai 17.00 WIB) (Virgiawan, 2015). Adapun lokasi pengambilan sampel pada penelitian ini terbagi menjadi 3 stasiun, yaitu:

1. Tepi Waduk DAM Duriangkang. Vegetasi didominansi oleh tumbuhan air yaitu eceng gondok dan teratai yang berada di badan air. Kawasan ini merupakan kawasan terbuka yang sering dilewati masyarakat dan berbatasan dengan Hutan Bumi Perkemahan Raja Ali Kelana.

2. Hutan Bumi Perkemahan Raja Aji Kelana. Vegetasi berupa semak dan hutan primer tua dengan tutupan tajuk yang cukup rapat.

3. Tepi jalan raya. Lokasi ini merupakan kawasan terbuka dekat jalan raya. Vegetasi berupa rerumputan, semak-semak, dan berada di sekitar genangan air yang ditumbuhi oleh tanaman keladi air.

Alat dan bahan yang digunakan dalam penelitian ini adalah insect net, jarum serangga, alat tulis, alat petunjuk waktu, buku panduan lapangan mengenal capung, termometer, jangka sorong, kamera, kertas segitiga, suntik gunting, toples, styrofoam board, alcohol, dan kapur barus. Capung yang dijumpai diidentifikasi dan didokumentasikan. Identifikasi dengan mencocok menggunakan buku panduan identifikasi Odonata berdasarkan morfologi 
sayapnya, warna, dan karakter lokasi perjumpaanya; spesimennya difoto keseluruhan bagian tubuhnya dan diukur berdasarkan panjang tubuhnya. Jumlah capung yang dijumpai dari tiap jenis capung dicatat di setiap lokasi. Secara umum, lokasi penelitian dapat dilihat pada Gambar 1 berikut.

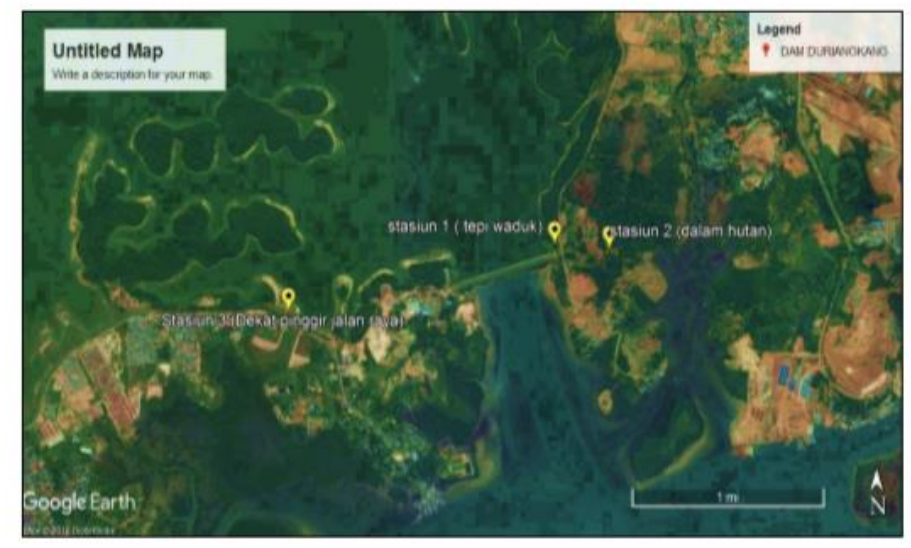

Gambar 1. Lokasi Pengambilan Sampel Penelitian

Analisis data struktur komunitas berupa Indeks Keanekaragaman Jenis (Shanon-Wiener Index), Kekayaan Jenis (Margalef index), Kemerataan Jenis (Simpson Index), Indeks Dominansi Jenis (D), dan Indeks Kesamaan (Similarity Index) dengan rumus sebagai berikut:

1. Indeks Keanekaragaman Jenis (Shanon-Wiener Index)

$$
\mathrm{H}^{\prime}=-\sum_{i=1}^{n} P i \ln P i
$$

Keterangan :

$\mathrm{H}$ ' = Indeks keanekaragaman Shanon-Wiener; Pi = Proporsi jumlah individu jenis ke-I terhadap jumlah individu total; $(\mathrm{Pi}=\mathrm{ni} / \mathrm{N}) ; \ln =$ logaritma natural

2. Kekayaan Jenis (Margalef index)

$$
\mathbf{D}_{\mathrm{mg}}=\frac{S-1}{\ln (N)}
$$

Keterangan :

Dmg = indeks kekayaan jenis; $\mathrm{S}=$ jumlah jenis; $\ln =$ logaritma natural; $\mathrm{N}=$ Total jumlah individu seluruh jenis.

3. Indeks Kemerataan Jenis (Simpson Index)

$$
\mathrm{E}=\frac{H^{\prime}}{H^{\prime} \max }
$$

Keterangan :

$\mathrm{E}=$ Indeks kemerataan (evenness); H' = Indeks keanekaragaman; Ln = Logaritma natural; $\mathrm{S}=$ jumlah jenis. 
4. Indeks Dominansi Jenis (D)

$$
\mathrm{D}=\sum P i^{2}=\sum\left(\frac{n i}{N}\right)^{2}
$$

Keterangan :

$\mathrm{D}=$ Indeks dominansi Simpson; $\mathrm{Pi}=$ Proporsi jenis ke-i dalam komunitas; $\mathrm{ni}=$ jumlah individu jenis ke-i; $\mathrm{N}=$ jumlah total individu jenis .

5. Indeks Kesamaan (Similarity Index)

$$
\mathrm{IS}=\frac{2 \mathrm{c}}{\mathrm{a}+\mathrm{b}} \times 100 \%
$$

Keterangan :

$\mathrm{a}=$ jumlah jenis yang hanya ditemukan di komunitas $\mathrm{A} ; \mathrm{b}=$ jumlah jenis yang hanya ditemukan dikomunitas $\mathrm{B} ; \mathrm{c}=$ jumlah jenis yang sama ditemukan di komunitas A dan B.

\section{HASIL DAN PEMBAHASAN}

Pada penelitian yang dilakukan di Kawasan Hutan Lindung Duriangkang ditemukan 429 individu capung, yang terdiri dari 24 spesies dan 4 Famili. Pada Tabel 1 dapat dilihat bahwa jumlah individu terbanyak adalah pada stasiun 1 dan 3, yaitu masing-masing 170 dan 167 individu. Jumlah ini hampir dua kali lipat lebih banyak dibadingkan stasiun 2 yang hanya 92 individu. Hal ini disebabkan karena stasiun 1 dan 3 merupakan kawasan terbuka dengan vegetasi utama semak dan berdekatan dengan badan perairan. Sementara stasiun 2 merupakan hutan sekunder dengan tutupan tajuk yang cukup rapat serta jauh dari badan perairan.

Jumlah spesies terbanyak pada stasiun 3 (17 jenis), stasiun 1 (15 jenis), dan yang paling sedikit adalah stasiun 2 (11 jenis). Berdasarkan data tersebut dapat dilihat bahwa jumlah jenis berbanding lurus dengan jumlah individu pada setiap stasiun pengamatan, dimana capung lebih banyak dijumpai di kawasan terbuka yang dekat dengan badan perairan. Hal ini sesuai dengan yang dinyatakan oleh (Susanti, 1998) bahwa capung dewasa sering terlihat di tempattempat terbuka, terutama di perairan tempat mereka berkembang biak dan berburu makanan.

Sebagian capung senang hinggap pada pucuk rumput, perdu dan lain-lain yang tumbuh di sekitar kolam, sungai, parit atau genangan-genangan air lainnya. Disamping itu vegetasi air yang hidup di perairan air tawar juga menentukan kehadiran capung karena berperan sebagai tempat melekatkan telur bagi sebagian besar capung (Sigit et. al., 2013). Jenis-jenis capung yang ditemukan di Hutan Lindung Duriangkang disajikan dalam Tabel 1 berikut. 
Tabel 1. Jenis-Jenis Capung di Hutan Lindung Duriangkang

\begin{tabular}{|c|c|c|c|c|c|}
\hline & \multirow{2}{*}{ Famili/Jenis } & \multicolumn{4}{|c|}{ Jumlah Individu } \\
\hline & & Stasiun 1 & Stasiun 2 & Stasiun 3 & Total \\
\hline \multirow[t]{5}{*}{ A. } & Coenagrionidae & & & & \\
\hline & 1. Agriocnemis femina & 7 & - & 3 & 10 \\
\hline & 2. Ischnura senegalensis & 24 & - & 21 & 45 \\
\hline & $\begin{array}{l}\text { 3. Paracercion malayanum } \\
\text { 4. Pseudagrion }\end{array}$ & - & - & 2 & 2 \\
\hline & microcephalum & 6 & - & 1 & 7 \\
\hline \multirow[t]{2}{*}{ B. } & Gomphidae & & & & 0 \\
\hline & 5. Ictinogomphus decorates & & 3 & 10 & 13 \\
\hline \multirow[t]{19}{*}{ C. } & Libellulidae & & & & 0 \\
\hline & 6. Acisoma panorpoides & - & - & 5 & 5 \\
\hline & 7. Aethriamanta aethra & 28 & 5 & - & 33 \\
\hline & 8. Brachydiplax chalybea & - & - & 13 & 13 \\
\hline & 9. Brachythemis contaminata & 11 & 8 & 20 & 39 \\
\hline & 10. Crocothemis servilia & 28 & 19 & 27 & 74 \\
\hline & 11. Macrodiplax cora & 9 & 7 & - & 16 \\
\hline & 12. Neurothemis fluctuans & 10 & - & 7 & 17 \\
\hline & 13. Neurothemis ramburii & - & - & 6 & 6 \\
\hline & 14. Neurothemis terminata & 9 & - & 3 & 12 \\
\hline & 15. Orthetrum chrysis & 2 & 3 & - & 5 \\
\hline & 16. Orthetrum glaucum & - & 4 & - & 4 \\
\hline & 17. Orthetrum sabina & 2 & - & 13 & 15 \\
\hline & 18. Orchithemis pruinans & - & 1 & - & 1 \\
\hline & 19. Rhodothemis rufa & - & - & 1 & 1 \\
\hline & 20. Rhyothemis phyllis & 20 & 26 & 19 & 65 \\
\hline & 21. Trithemis aurora & 8 & 7 & - & 15 \\
\hline & 22. Tholymis tillarga & - & - & 8 & 8 \\
\hline & 23. Urothemis signata & 2 & 9 & 8 & 19 \\
\hline \multirow[t]{3}{*}{ D. } & Platycnemididae & & & & 0 \\
\hline & 24. Copera marginipes & 4 & - & - & 4 \\
\hline & JUMLAH & 170 & 92 & 167 & 429 \\
\hline
\end{tabular}

Keterangan: $(-)=$ Capung tidak ditemukan

Kehadiran capung di perairan mengalir dan menggenang sebagai habitat fase pra dewasa, serta sering terlihat di kawasan terbuka dan sangat mendukung capung untuk beraktivitas seperti berjemur dibawah terik matahari dan hinggap di atas permukaan; terlihat juga minimnya cemaran di kawasan tersebut juga merupakan salah satu penunjang keanekaragaman tersebut. Hal ini sependapat dengan Samways, (2008) yang menyatakan bahwa hal ini disebabkan oleh ketertarikan capung terhadap permukaan yang terlihat berkilau saat tertimpa matahari sehingga memegang peranan penting bagi keberadaan jenis capung. 
Secara keseluruhan, indeks keanekaragaman capung di hutan lindung Duriangkang tergolong sedang yaitu 2,709. Nilai indeks keanekaragaman pada masing-masing stasiun pengamatan tidak jauh berbeda, nilai indeks tertinggi pada stasiun 1 sebesar $\mathrm{H}^{\prime}=2,415$, berikutnya stasiun 3 sebesar $H^{\prime}=2,362$ dan yang paling rendah stasiun 2 sebesar $H^{\prime}=2,082$. Hal ini menunjukkan bahwa struktur komunitas pada kawasan tersebut memiliki kualitas yang stabil atau tergolong sedang dengan kriteria $1<\mathrm{H}^{\prime}<3$.

Indeks kekayaan jenis capung di ketiga stasiun berkisar antara 2,43 - 3,126. Indeks kekayaan jenis pada tepi waduk yaitu 2.726, pada kawasan hutan bumi perkemahan diperoleh indeks kekayaan jenis yaitu 2.432, sedangkan stasiun 3 diperoleh indeks kekayaan yaitu 3,126. Indeks kekayaan total jenis capung pada seluruh kawasan Hutan Lindung Duriangkang sebesar 3.794 tergolong dalam kategori sedang dengan total 24 jenis capung yang ditemukan.

Nilai indeks kemerataan jenis pada masing-masing stasiun berbeda-beda. Indeks kemerataan jenis pada tepi waduk yaitu 0,892; pada hutan bumi perkemahan memiliki nilai indeks kemerataan yaitu 0,868; dan pada tepi jalan bagan memiliki indeks kemerataan yaitu 0.829. Nilai indeks kemerataan total yang diperoleh pada kawasan Hutan Lindung Duriangkang sebesar 0.852 sehingga menunjukkan bahwa kawasan Hutan Lindung Duriangkang memiliki nilai kemerataan jenis yang tergolong tinggi dengan kriteria $\mathrm{E}>0,6$. Hal ini dikarenakan kondisi tempat hidup capung yang mendukung pada semua stasiun penelitian dengan penyebaran jenis dalam suatu komunitas merata.

Nilai indeks dominansi pada kawasan tepi waduk yaitu sebesar 0.107, kawasan hutan bumi perkemahan yaitu sebesar 0.158 , dan kawasan tepi jalan bagan yaitu sebesar 0.094 Analisis data dominansi pada setiap staisun penelitian menunjukkan hasil yang seragam, yaitu adanya dominansi yang tergolong rendah disetiap stasiun pengamatan. Adapun nilai indeks dominansi total yang diperoleh pada kawasan Hutan Lindung Duriangkang sebesar 0.090 dengan Penentuan nilai dominansi ini berfungsi untuk mengetahui atau menetapkan jenis-jenis capung yang dominan atau bukan (Suharto, 2017).

Walaupun nilai indeks dominansi rendah, namun pada penelitian juga dijumpai jenis yang jumlahnya individunya lebih banyak dibandingkan jenis lain pada setiap stasiun pengamatan yaitu Crocothemis servilia dan Aethriamanta aethra (pada stasiun 1), Rhyothemis phyllis (pada stasiun 2), dan Crocothemis servilia dan Ischnura senegalensis (pada stasiun 3). 
Nilai indeks kesamaan jenis capung di kawasan Hutan Lindung Duriangkang berkisar 36\% - 63\%. Diketahui Indeks kesamaan jenis pada kawasan Tepi Waduk dan kawasan Hutan Bumi perkemahan yaitu sebesar $62 \%$, pada kawasan tepi waduk dan tepi jalan bagan yaitu sebesar $63 \%$, sedangkan nilai indeks kesamaan Hutan Bumi perkemahan dan tepi jalan bagan diketahui sebesar 36\%. Hasil Jenis capung yang ditemukan pada kawasan tepi waduk dan tepi jalan bagan memiliki kesamaan jenis yang tinggi dan nilai indeks kesamaan komunitas mendekati $100 \%$ artinya komunitas tersebut memiliki kemiripan spesies yang sama. Hal ini terlihat dari kesamaan jenis capung yang ditemukan sama sebanyak sepuluh jenis dikarenakan kedua kawasan tersebut merupakan kawasan yang terbuka berdekatan dengan tepi waduk serta kondisi lingkungan yang dekat dengan perairan.

Hal yang sama juga di laporkan oleh peneliti sebelumnya. Setiyono et. al., (2017) mengatakan bahwa keberadaan capung berhubungan erat dengan keberadaan air sebagai habitat dari capung tersebut. Hal ini berbeda dengan penelitian yang dilakukan oleh Irawan et. al., (2017) yang menyatakan bahwa habitat perairan tanpa kanopi memiliki habitat yang kurang bervariasi karena di sekitar sungai hanya terdapat vegetasi kebun pada dan semak sehingga perolehan jumlah spesies capung pagi dan sore sedikit yaitu 5 spesies.

Family Libellulidae adalah famili yang paling banyak ditemukan dengan jumlah spesies sebanyak 18 jenis. Hal ini serupa dengan penelitian (Hedriyanti, 2018; Siregar, 2016; dan Hanum, 2013). Spesies capung biasa yang banyak di temukan di setiap stasiun adalah jenis Crocothemis servilia dari famili Libellulidae dengan total individu sebanyak 74 individu dimana jenis capung ini merupakan jenis capung yang sangat umum ditemukan dan tersebar luas didaerah daratan rendah dan perbukitan (Gustia, 2013). Hal ini sejalan dengan penelitian yang dilakukan Ansori (2009) yang menyatakan bahwa jenis Crocothemis servilia merupakan spesies yang paling banyak ditemukan diseluruh lokasi penelitian. Keberadaan spesies ini di temukan berkoloni atau berkelompok.

Menurut Susanti, (1998) capung melakukan kegiatannya pada siang hari ketika terik matahari. Oleh karena itu, ketika cuaca cerah dan panas, capung akan terbang sangat aktif dan sulit untuk didekati. Pada dini hari, senja hari, dan saat matahari terbenam, kadangkadang capung relatif mudah didekati. Pada sore hari capung sangat sedikit ditemukan karena kurang sinar matahari.

Berdasarkan analisis struktur komunitas, struktur komunitas capung dapat diindikasikan bahwa lingkungan kawasan Hutan Lindung Duriangkang masih terjaga, karena 
capung berfungsi sebagai bioindikator suatu lingkungan yang tercemar, dimana capung sangat menyukai lingkungan air yang bersih dan kategori serangga yang anti polutan (Siregar, et al. 2004 dalam Siregar, 2016).

\section{KESIMPULAN}

Nilai indeks Keanekaragaman total Jenis sebesar 2.709 yang tergolong sedang. Indeks Kemerataan (E) Jenis sebesar 0.852 yang tergolong tinggi. Indeks Kekayaan jenis sebesar 3.794 yang tergolong sedang, indeks Dominansi total sebesar 0.090 yang tergolong kategori rendah atau tidak terdapat jenis yang mendominansi. Indeks Kesamaan Jenis yang diperoleh dari perbandingan stasiun 1-2 dan 1-3 tergolong sama (62\% dan 63\%) dan indeks kesamaan jenis dari stasiun 2-3 tergolong berlainan (36\%) sehingga kualitas ekosistem pada kawasan Hutan Lindung Duriangkang tergolong stabil dan merata. Kehadiran capung sangat erat kaitannya dengan keberadaan badan perairan di suatu habitat, lebih menyenangi habitat terbuka dengan vegetasi semak dibandingkan hutan dengan hutan dengan tutupan tajuk yang rapat.

\section{REFERENSI}

Amir, M., dan Kahano, 2003. Serangga Taman Nasional Gunung Halimun Jawa Bagian Barat. Biodiversity Conservation Project. Jawa Barat.

Ansori, I., 2009. Kelimpahan dan dinamika Populasi Odonata Berdasarkan Hubungannya dengan Fenologi Padi di Beberapa Persawahan Sekitar Bandung Jawa Barat. Jurnal ExactaI 7(2): 69-75.

Borror, D. J., Triplehorn, C. A., \& Johnson, N. J., 1992. Pengenalan pelajaran serangga. Gadjah Mada University. Yogyakarta.

Cafferty, W. P. M., 1981. Aquatic Entomology. Jones and Bartlett. Boston, 125-147.

Gustia, N., Jasmi, dan Pratiwi, P., 2013. Kepadatan populasi capung Crocothemis servilia (odonata: Libellulidae) pada pertanaman padi sawah di Kelurahan Anduring Kecamatan Kuranji Padang Sumatera Barat. Jurnal Pendidikan Biologi, 1(1): 1-5.

Hadi, H., Mochamad, Tarwotjo, Udi dan Rahadian, Rully, 2009. Biologi Insekta Entomologi (Edisi Pertama). Graha Ilmu, Yogyakarta. $162 \mathrm{hlm}$.

Irawan, F., Hadi, M., dan Tarwotjo, U., 2017 Struktur Komunitas Odonata Dikawasan Wana Wisata Curug Semirang Kecamatan Ungaran Barat, Semarang, Jurnal Bioma, 19 (1): 69-75. 
Pamungkas, D.W., dan Ridwan, M., 2015. Keragaman jenis capung dan capung jarum (Odonata) di beberapa sumber air di Magetan, Jawa Timur. Prosiding SeminarNasional Masyarakat Biodiversitas Indonesia, Vol. 1(6): 1295-1301.

Rizal, S., dan Hadi, M., 2015. Inventarisasi Jenis Capung (Odonata ) Pada Areal Persawahan Di Desa Pundenarum Kecamatan Karangawen Kabupaten Demak. Jurnal Bioma,Vol. 17(1): 16-20.

Samways, M. J., 2008. Dragonflies and Damselflies of Sout Africa. Pensoft Publishers. Sofia.

Setiyono, J., Diniarsih, S., Oscilata E. N. R., dan Budi, N. S., 2017. Dragonflies of Yogyakarta, Jenis Capung Daerah Istimewa Yogyakarta, Indonesia Dragonnfly Society, Yogyakarta.

Sigit, W., 2013. Keanekaragaman capung perairan Wendit, Malang, Jawa Timur, Indonesia Dragonfly Society. Malang.

Siregar, A. Z., 2016. keanekaragaman dan konservasi status capung dikampus hijau Universitas Sumatera Utara, Medan - Indonesia. Jurnal Pertanian Tropik Kultura, Vol. 3(1): 25-30.

Suharto, A., 2017. Biodiversity Area Konservasi Pantai Randutatah. PT. Lafirza Global Indonesia, Probolinggo.

Susanti, 1998. Seri Panduan Lapangan Mengenal Capung. Pusatlitbang Biologi - Lipi. Bogor.

Virgiawan, C., Hindun, I., dan Sukarsono, 2015. Studi Keanekaragaman Capung (Odonata) Sebagai Bioindikator Kualitas Air Sungai Brantas Batu-Malang Dan Sumber Belajar Biologi. Jurnal Pendidikan Biologi, Vol. 1(2): 188-196.

Wijayanto, Nafisah, Laily, dan Zaman, 2016. Inventarisasi capung (insecta: odonata) dan variasi habitatnya di resort tegal bunder dan teluk terima Taman Nasional Bali Barat (TNBB). Jurnal Seminar nasional pendidikan dan saintek, Vol. (1): 427-434. 